\title{
Why telecoupling needs to account for environmental justice
}

\author{
Engaging with normative questions in land system science is a key challenge. \\ This debate paper highlights the potential of incorporating elements of \\ environmental justice scholarship into the evolving telecoupling framework that \\ focuses on distant interactions in land systems. We first expose the reasons why \\ environmental justice matters in understanding telecoupled systems, and the \\ relevant approaches suited to mainstream environmental justice into telecoupled \\ contexts. We then explore which specific elements of environmental justice need \\ to be incorporated into telecoupling research. We focus on 1) the distribution of \\ social-ecological burdens and benefits across distances, 2) power and justice \\ issues in governing distantly tied systems, and 3) recognition issues in \\ information flows, framings and discourses across distance. We conclude our \\ paper highlighting key mechanisms to address injustices in telecoupled land \\ systems.
}

Keywords: telecoupling, environmental justice, ecosystem services, power, governance, decolonial thought

Word count: 2999 words

\section{Introduction}

The expansion of socio-economic globalization has widened the distance between the benefits and costs of land use change. For example, soybean imports have enabled China to avoid domestic agricultural expansion and spare land for afforestation (Torres, Moran, \& Silva, 2017), but have led to deforestation in exporting countries including Brazil and Argentina (Garrett, Lambin, \& Naylor, 2013; Vallejos et al., 2015). In Argentina, soybean expansion in the Chaco region has displaced indigenous peoples and small-scale farmers (Cáceres, 2015; Leguizamón, 2016), and exposed them to flooding and reduced availability of forest products (Camino, Cortez, Altrichter, \& Matteucci, 2018). Furthermore, the conversion of soybean fields to corn and paddy increased nitrogen pollution in former soybean production areas in China, such as the 
Heilongjiang province (Sun et al., 2018), affecting vulnerable social groups such as children (Zhai et al., 2017).

This example shows how land use change generates social-ecological impacts across distance and scales. The concept of telecoupling helps to explore these effects by linking globalization with land use change (Eakin et al., 2014; Friis et al., 2016; Lenschow, Newig, \& Challies, 2016; Liu et al., 2013). Telecoupled systems are distantly connected social-ecological systems sending and receiving goods and services, energy matter, information and living species through their enabling agents (Liu et al., 2013). The connected systems (in the example above, deforested lands in Argentina and Brazil and spared land in China) can also directly or indirectly affect additional "spillover" systems (in the example above, Canada, Russia, Belarus and Germany as fertilizer producers [Liu et al., 2018], and nitrogen pollution sources in China). The novelty and analytical potential of a telecoupling lens is to reveal such distant ties from a social-ecological perspective, while earlier approaches have focused either on ecological or socio-economic aspects (Liu et al., 2013). Nevertheless, telecoupling studies still need to engage with normative questions in order to deal with the moral consequences of decision-making (Nielsen et al., 2019). This has not happened systematically yet (Corbera, Busck-Lumholt, Mempel, \& Rodríguez-Labajos, 2019). We contend that an environmental justice lens can contribute significantly to critically reflect and operationalize the normative dimensions of telecouplings.

In what follows, we first explain why environmental (in)justices are fundamental features of telecoupled systems. We demonstrate why telecoupled systems produce social and environmental inequalities qualified as unjust, and which approaches of environmental justice are most suited for analysing these situations. Secondly, we explore which elements of environmental justice can and should already be incorporated 
in telecoupling research, and which new research domains and questions arise as a result. We conclude by highlighting possible mechanisms towards achieving greater environmental justice in telecoupled systems.

\section{Why telecoupling needs environmental justice}

Because sending and receiving goods through distance implies a redistribution of the environmental costs of their production, environmental inequality is prominent in telecoupled systems. In the introduction example, soybeans are consumed in Europe and China while the environmental burdens concentrate at the producing locations in South America. There is wide empirical evidence that more affluent people and economies can shift the environmental costs of their consumption, such as carbon emissions (Xiong, Millington, \& Xu, 2018) or deforestation (Jorgenson, 2006) to distant places. In these places, land use changes due to the production of global commodities have strong negative impacts on socio-economically disadvantaged and disempowered social groups (Borras, Franco, Kay, \& Spoor, 2011; Peluso \& Lund, 2011).

Hornborg (1998) explains the mechanisms that lead to global environmental inequalities through the theory of ecological unequal exchange (EUE). EUE postulates that though raw materials have a greater productive potential and that their extraction has high environmental impacts, their monetary value is lower than processed goods (Givens, Huang, \& Jorgenson, 2019). In a connected global system where nations have historically unequal positions (Wallerstein, 1984), centres of consumption concentrate exchange value while they undermine the productive potential that they absorb through trade from their peripheries. This accumulation of exchange value allows centres to further extract raw materials and cheap labour at their periphery (Martinez-Alier, 2009) and systematically shift environmental burdens and social costs onto those who have less access to consumption of goods and services (Fitzgerald \& Auerbach, 2016; Rice, 
2007). Though the periphery often corresponds to the Global South, unequal exchange and core-periphery dynamics work both within and between nations (Dunaway \& Clelland, 2016; W. Zhang et al., 2018), as the nitrogen pollution in China in the soybean example shows.

Why is justice an appealing concept for analysing such unequal socialecological exchange? Justice is a fundamental evaluative criteria in moral philosophy (Rawls, 1971; Sen, 2009). John Locke (2005 [1690]) showed that justice has an intrinsic value ensuring people the opportunities for a life worth living, as well as an instrumental value (as a 'social contract' in Locke's terms) because justice is considered to be a condition that enables collective action towards goals such as sustainability (Martin, 2013: 99). This bivalent intrinsic/instrumental notion of justice is visible in sustainability literature. For example, the concept of a safe and just operating space postulates that ending poverty while staying within earth's limits should only be achieved by greater equity besides greater efficiency (Dearing et al., 2014; Leach, Raworth, \& Rockström, 2013).

In telecoupled systems, nevertheless, sustainability and justice might not be two separate conditions as usually framed. EUE suggests that unsustainable and unjust conditions tend to be causally inter-linked. Empirical evidence shows that more unequal societies tend to have more degraded environments, in particular air and water (Cushing, Morello-Frosch, Wander, \& Pastor, 2015). Inversely, socially just environmental measures and policies are more likely to be effective (Brondizio \& Le Tourneau, 2016; Pascual et al., 2014). Boyce (2018) explains this link through the power-weighted social decision rule: powerful people and nations are less likely to address environmental costs when they can shift them to others who lack sufficient economic and political power to take environmentally relevant decisions. 
We postulate that environmental justice provides the most developed framing to understand environmental inequalities and their causes in telecoupled systems.

Environmental justice has expanded its initial focus on characterizing environmental burdens among disadvantaged groups (Bullard, 1994) to understand the causes of these inequalities as well as justice claims, discourses and practices in environmental issues (Holifield, Porter, \& Walker, 2009). Schlosberg $(2007,2013)$ has shown that environmental justice issues and claims work along three dimensions: 1) the distribution of environmental burdens and benefits, 2) procedural justice, the fairness and autonomy of environmental decisions-making and 3) recognition justice including issues of rights, power, and respect for cultural differences in knowing and shaping the environment (Martin, 2013).

This framing is particularly relevant for telecoupling research. A distributive environmental justice lens can help to identify the telecoupling dynamics and flows that matter from a normative point of view. Procedural and recognition justice contribute to integrate a power perspective in telecoupling research. Finally, incorporating the study of environmental justice movements can enhance the understanding of feedback processes and their potential to make telecoupled systems more just and sustainable.

Despite the relevance of environmental justice issues in telecoupling, few studies have addressed it explicitly. A recent review of 48 telecoupling studies (Corbera et al., 2019) found only three contributions that integrate justice explicitly, and also found that those studies that do integrate justice implicitly generally concentrate on distributive equity aspects. This suggests that environmental justice and telecoupling have remained largely disconnected in the global land systems and sustainability science literatures, with few exceptions (e.g. Boillat et al., 2018; Lundsgaard-Hansen et al., 2018; Oberlack et al., 2018; Schröter et al., 2018; Zimmerer, Lambin, \& Vanek, 
2018). In the next sections, we discuss each dimension of environmental justice and which related questions and empirical approaches could help enriching the study of telecoupled systems. The table in supplementary material summarizes these questions.

\section{Elements of environmental justice to incorporate into telecoupling}

\section{Distributive justice: benefits and burdens across distances}

In telecoupled systems, distributive justice is about the benefits and burdens generated by social-ecological flows across distances. This includes "embedded" natural resources and emissions in commodities, such as virtual water (Hoekstra \& Mekonnen, 2012), land (Yu, Feng, \& Hubacek, 2013; J. Zhang, Zhao, Liu, \& Liu, 2016), and greenhouse gases (Xiong et al., 2018). Schröter et al. (2018) conceptualize environmental benefits in telecoupled systems as benefits from interregional flows of ecosystem services, including trade of goods, active and passive biophysical flows and information flows between systems. Pascual et al. (2017) identify negative impacts through ecosystem service burdens that can be distant but also delayed and spatially diffuse.

Assessing cultural and regulating ecosystem services involves dealing with complexity and uncertainty (Schröter et al., 2018) and requires choices (such as scale parameters) that cannot be innocent of politics or other values. The ecosystem service framing in itself represents a utilitarian conception of nature and justice that cannot be assumed to be shared among the actors involved (Díaz et al., 2018; Sikor, 2014). Assessing distributive justice in telecoupled systems should therefore include knowledge co-production methods that combine accounting of the diversity of perceptions about nature's contributions to people's quality of life (beyond a utilitarian ecosystem service flow framing) (Ellis, Pascual, \& Mertz, 2019) with empirical, 
bottom-up accounts from involved actors (Sikor, Martin, Fisher, \& He, 2014; Zaehringer, Schneider, Heinimann, \& Messerli, 2019).

Ecosystem services also often focus only on those social outcomes that arise from ecological change (Lele, Springate-Baginski, Lakerveld, Deb, \& Dash, 2013) and would thus miss the effects of telecouplings that directly affect social outcomes, for example when distant trade flows affect the labour practices in connected systems $(\mathrm{Li}$, 2011). The distribution of labour, terms of trade, entitlements and the control of land and natural resources in telecoupled systems needs to be investigated. In turn, the distribution of these assets can feed back into how environmental benefits and burdens affect differentiated social groups. For example, a narrow ecosystem service framing focusing on landowners may overlook service providers who lack formal recognition such as land tenants, informal users and women. Social differentiation must therefore be examined carefully in its multi-dimensional forms (Daw, Brown, Rosendo, \& Pomeroy, 2011; Dawson \& Martin, 2015).

\section{Procedural justice: decision-making spaces, actors and power}

Procedural justice is about the extent to which legitimate voices and interests of individuals and social groups are represented in decision-making. One first needs to identify the relevant decision-making spaces, namely the set of collectively binding, coordination and steering decisions gathered under the broad concept of governance (Newig, Lenschow, Challies, Cotta, \& Schilling-Vacaflor, 2019). In telecoupled systems, these governance spaces can concern focal or distant territorial systems as well as flow-based governance between these systems (Oberlack et al., 2018; Sikor et al., 2013) Researching flow-based governance implies to pay more attention to the network of vertical and horizontal norms, institutions and power relations governing production 
networks, contract farming, commodity and value chains (Adams, Gerber, Amacker, \& Haller, 2018; Gibbon, Bair, \& Ponte, 2008).

Second, one needs to inquire about who is potentially affected by decisions under governance spaces that favour telecoupling. This refers to distributive justice, but also considers how the different actors involved define the subjects of justice, namely those considered legitimate holders of claims to land, ecosystem services and benefits (Sikor et al., 2014). In telecoupled systems that typically cross borders, subjects of justice cannot be restricted to members of a sovereign nation-state as Rawlsian theory does (Fraser, 2010a). They may be defined through the all-subjected principle (Fraser, 2010b) which posits that all people that are affected by governing decisions taken in relation with a telecoupling process or a telecoupled system are subjects of justice.

We finally need to look at the relation between the relevant governance spaces, and the participation and power of potentially affected subjects across distant places. From an institutional analysis perspective (Ostrom, 2005), the social spaces in which actors interact and make decisions are called action situations (Ostrom, 2011). In telecoupled systems, local, distant and flow-centered action situations interact in networks and constitute polycentric governance systems (Oberlack et al., 2018). We hypothesize that the position of actors across action situation types and their ability to bridge physical, social or institutional distances has a strong relation with their power (Boillat et al., 2018; Eakin, Rueda, \& Mahanti, 2017; Kashwan, 2015).

\section{Recognition justice: information flows, framings and discourses}

Recognition injustices involve harms linked to discrimination and domination, produced through formal rules (e.g. tenure rules that discriminate against women) as well as informal norms (e.g. prevailing traditional institutions that prevent women controlling land) that disregard some people to make legitimate claims. Structural inequalities are 
expressed at multiple scales through institutions, practices, language and symbols, producing problem framings that strongly influence distributive and procedural outcomes (Fraser, 2000; Schlosberg, 2007; Young, 1990).

At a global scale, there is particular attention in environmental justice literatures to the recognition injustices linked to coloniality (Álvarez \& Coolsaet, 2018; Martin et al., 2016; Rodriguez, 2013; Rodríguez \& Inturias, 2018). Coloniality postulates that environmental injustices arise because governance spaces are driven by dominant knowledge and values, which in turn shape both problem analysis and solutions in ways that reflect and reproduce colonial power asymmetries and reinforce social distance (De Sousa Santos, 2010). From a telecoupling perspective, these spaces embody and project dominant conceptions of nature in distant places. Safeguards to 'recognise' local or indigenous community rights might exist, but within a colonial politics of recognition that requires to assimilate dominant values that are in turn sedimented by legitimized epistemic communities, e.g. by entering into compensation or benefit-sharing schemes that are rooted it the same imposed knowledge system (Martin et al., 2016).

We thus propose to integrate recognition justice concerns into telecoupling through an examination of discourses, scale choices, evidence framing, views on nature and views of justice expressed in information flows from a decolonial or more generally critical perspective on dominant values. This focus emphasizes that 'information flows' are rarely if ever innocent of injustice. Information is entangled with issues of 'whose knowledge', 'whose values' and ultimately 'whose justice' is made visible or invisible. Such questions are relevant to everyday practices that are presented as neutral but are in fact deeply political, such as choices over appropriate scales of analysis (Towers, 2000), what subjects of justice are considered (Sikor et al., 2014), what kind of evidence is admissible, and so on. To enhance recognition justice, our analysis of telecoupled 
systems should therefore employ a 'thickened' sense of information flows that asks whose knowledge, values and interests are considered, and whose are rendered invisible.

\section{Addressing injustices in telecoupled systems}

Overall, telecouplings do create the conditions for some people to bear adverse effects (burdens) in both social and ecological terms. We postulate that these people - often disempowered, marginalized and invisibilized communities - can be key allies for sustainability. What are then the possible mechanisms to address these injustices?

First, environmental injustices often trigger social movements (Martinez-Alier, Temper, Del Bene, \& Scheidel, 2016), that are increasingly interconnected around common values, concerns and interests (Anguelovski \& Martínez Alier, 2014; Temper, Demaria, Scheidel, Del Bene, \& Martinez-Alier, 2018). Through the boomerang mechanism (Keck \& Sikkink, 1998: 12-13), local activists can purposefully seek transnational allies to draw attention to the existing injustices, mobilize international leverage and eventually reshape power asymmetries (Keck \& Sikkink, 1998; Veuthey \& Gerber, 2012). These allies can include foreign and international NGOs (Carruthers, 2008; Keck \& Sikkink, 1998), financial and trade organizations (Nelson, 2002), courts and tribunals (Spalding, 2017) or company shareholders (McAteer \& Pulver, 2009). This mechanism can potentially empower marginalized subjects of justice, defend community rights and resources, reinvigorate local identities and better recognition of local ecological knowledge (Oberlack, Tejada, Messerli, Rist, \& Giger, 2016;

Villamayor-Tomas \& García-López, 2018).

The catapult mechanism describes the inverse setting, in which transnational actors such as international NGOs initiate alliances with local actors. They can harmonize their own agenda with local environmental justice struggles (Temper, 2019) 
and proactively support the agency of local resource users (Lundsgaard-Hansen et al., 2018). Resistance movements can also scale of their effects through the minefield mechanism, through which highly conflictive projects can change the overall perception of similar projects (e.g. in terms of risk and profitability), leading to alterations in investment behaviour, legal action, or regulatory changes (Temper, 2019). For example, wide-spread citizen resistance enhanced the open pit mining ban in Costa Rica in 2010 (Broad \& Fischer-Mackey, 2017).

Finally, an increasing number of initiatives attempt to transform justice conflicts in natural resource use through enhanced transparency (Anseeuw, Lay, Messerli, Giger, \& Taylor, 2013; Gardner et al., 2019). Better public access to information, including environmental data, can constrain elites to extract resource rents and to form patronage networks (Corrigan, 2014; Dillon et al., 2017). Transparency initiatives may provide new means of participation and accountability in land and resource governance (Mejía Acosta, 2013; Vijge, Metcalfe, Wallbott, \& Oberlack, 2019). Taken together, these mechanisms can co-occur and interact. More mechanisms to transform injustices in telecoupled systems exist for instance through global institutions or states (Lenschow et al., 2016). Future research needs to delineate them clearly and to identify the precise conditions under which particular mechanisms do and do not operate effectively.

\section{Conclusion}

In this article, we have advocated for the inclusion of a justice perspective in telecoupling research. We have shown how social-ecological flows across distances create winners and losers, how to assess them and under which conditions injustices can be reduced. Because telecouplings are social-ecological interactions, some people in some contexts are likely to bear adverse effects in both social and ecological terms while, in other contexts, telecouplings might not necessarily translate into subjectively 
felt injustices. In this regard, we would refer to the Rawlsian principle that only processes which do achieve better conditions for the worst off can be labelled as just.

Specifically, we have argued for the incorporation of procedural and recognition perspectives in telecoupling research, which pays increased attention to governance systems, power, discourses and values. Such perspective can contribute to a richer understanding of which mechanisms create and reproduce injustices at different scales for different actors in telecoupled systems. This will also complement other existing approaches that explain environmental injustice through a socio-metabolic, global perspective (Martinez-Alier et al., 2016).

\section{References:}

Adams, T., Gerber, J.-D., Amacker, M., \& Haller, T. (2018). Who gains from contract farming? Dependencies, power relations, and institutional change. The Journal of Peasant Studies, 1-23.

Álvarez, L., \& Coolsaet, B. (2018). Decolonizing Environmental Justice Studies: A Latin American Perspective. Capitalism Nature Socialism, 1-20.

Anguelovski, I., \& Martínez Alier, J. (2014). The 'Environmentalism of the Poor' revisited: Territory and place in disconnected glocal struggles. Ecological Economics, 102, 167-176.

Anseeuw, W., Lay, J., Messerli, P., Giger, M., \& Taylor, M. (2013). Creating a public tool to assess and promote transparency in global land deals: the experience of the Land Matrix. The Journal of Peasant Studies, 40(3), 521-530.

Boillat, S., Gerber, J.-D., Oberlack, C., Zaehringer, J. G., Ifejika Speranza, C., \& Rist, S. (2018). Distant interactions, power and environmental justice in protected area governance: a telecoupling perspective. Sustainability, 10(1), 3954.

Borras, S. M. J., Franco, J. C., Kay, C., \& Spoor, M. (2011). Land grabbing in Latin America and the Caribbean viewed from broader international perspectives. Santiago, Chile: FAO.

Boyce, J. K. (2018). The environmental cost of inequality. Scientifc American, November 2018, 73-77.

Broad, R., \& Fischer-Mackey, J. (2017). From extractivism towards buen vivir: mining policy as an indicator of a new development paradigm prioritising the environment. Third World Quarterly, 38(6), 1327-1349.

Brondizio, E. S., \& Le Tourneau, F.-M. (2016). Environmental governance for all. Science, 352(6291), 1272-1273.

Bullard, R. D. (1997). Unequal Protection: Environmental justice and communities of 
color. San Francisco, CA: Sierra Club Books.

Cáceres, D. M. (2015). Accumulation by Dispossession and Socio-Environmental Conflicts Caused by the Expansion of Agribusiness in Argentina. Journal of Agrarian Change, 15(1), 116-147.

Camino, M., Cortez, S., Altrichter, M., \& Matteucci, S. D. (2018). Relations with wildlife of Wichi and Criollo people of the Dry Chaco, a conservation perspective. Ethnobiology and Conservation, 2018, 7:11.

Carruthers, D. V. (2008). Environmental Justice in Latin America: Problems, promise, and practice. Cambridge, MA/London, UK: MIT Press.

Corbera, E., Busck-Lumholt, L. M., Mempel, F., \& Rodríguez-Labajos, B. (2019). Environmental Justice in Telecoupling Research. In C. Friis \& J. Ø. Nielsen (Eds.), Telecoupling: Exploring Land-Use Change in a Globalised World (pp. 213-232). London, UK: Palgrave Macmillan.

Corrigan, C. C. (2014). Breaking the resource curse: Transparency in the natural resource sector and the extractive industries transparency initiative. Resources Policy, 40, 17-30.

Cushing, L., Morello-Frosch, R., Wander, M., \& Pastor, M. (2015). The Haves, the Have-Nots, and the Health of Everyone: The Relationship Between Social Inequality and Environmental Quality. Annual Review of Public Health, 36(1), 193-209.

Daw, T., Brown, K., Rosendo, S., \& Pomeroy, R. (2011). Applying the ecosystem services concept to poverty alleviation: the need to disaggregate human well-being. Environ. Conserv., 38, 370.

Dawson, N., \& Martin, A. (2015). Assessing the contribution of ecosystem services to human wellbeing: A disaggregated study in western Rwanda. Ecological Economics, 117, 62-72.

De Sousa Santos, B. (2010). Descolonizar el saber, reinventar el poder. Montevideo, Uruguay: Ediciones Trilce.

Dearing, J. A., Wang, R., Zhang, K., Dyke, J. G., Haberl, H., Hossain, M. S., ... Poppy, G. M. (2014). Safe and just operating spaces for regional social-ecological systems. Global Environmental Change, 28, 227-238.

Díaz, S., Pascual, U., Stenseke, M., Martín-López, B., Watson, R. T., Molnár, Z., ... Shirayama, Y. (2018). Assessing nature's contributions to people. Science, $359(6373), 270-272$.

Dillon, L., Walker, D., Shapiro, N., Underhill, V., Martenyi, M., Wylie, S., ... Brown, P. (2017). Environmental Data Justice and the Trump Administration: Reflections from the Environmental Data and Governance Initiative. Environmental Justice, 10(6), 186-192.

Dunaway, W. A., \& Clelland, D. A. (2016). Challenging the global apartheid model: a world-systems analysis. Journal of World-Systems Research, 22(1), 16-22.

Eakin, H., DeFries, R., Kerr, S., Lambin, E., Liu, J., Marcotullio, P. J., ... Zimmerer, K. (2014). Significance of Telecoupling for Exploration of Land-Use Change. In K.C. Seto \& A. Reenberg (Eds.), Rethinking Global Land Use in an Urban Era (pp. 141-161). Cambridge MA/London: MIT Press. 
Eakin, H., Rueda, X., \& Mahanti, A. (2017). Transforming governance in telecoupled food systems. Ecology and Society, 22(4).

Ellis, E. C., Pascual, U., \& Mertz, O. (2019). Ecosystem services and nature's contribution to people: negotiating diverse values and trade-offs in land systems. Current Opinion in Environmental Sustainability, 38, 86-94.

Fitzgerald, J. B., \& Auerbach, D. (2016). The Political Economy of the Water Footprint: A Cross-National Analysis of Ecologically Unequal Exchange. Sustainability, $8(12)$.

Fraser, N. (2000). Rethinking recognition. New Left Review, 3, 107.

Fraser, N. (2010a). Who Counts? Dilemmas of Justice in a Postwestphalian World. Antipode, 41(1), 281-297.

Fraser, N. (2010b). Injustice at Intersecting Scales: On 'Social Exclusion' and the 'Global Poor.' European Journal of Social Theory, 13(3), 363-371.

Friis, C., Nielsen, J. Ø., Otero, I., Haberl, H., Niewöhner, J., \& Hostert, P. (2016). From teleconnection to telecoupling: taking stock of an emerging framework in land system science. Journal of Land Use Science, 11(2), 131-153.

Gardner, T. A., Benzie, M., Börner, J., Dawkins, E., Fick, S., Garrett, R., ... Wolvekamp, P. (2019). Transparency and sustainability in global commodity supply chains. World Development, 121, 163-177.

Garrett, R. D., Lambin, E. F., \& Naylor, R. L. (2013). Land institutions and supply chain configurations as determinants of soybean planted area and yields in Brazil. Land Use Policy, 31, 385-396.

Gibbon, P., Bair, J., \& Ponte, S. (2008). Governing global value chains: an introduction. Economy and Society, 37(3), 315-338.

Givens, J. E., Huang, X., \& Jorgenson, A. K. (2019). Ecologically unequal exchange: A theory of global environmental injustice. Sociology Compass, 13(5), e12693.

Hansen, M. C., Potapov, P. V., Moore, R., Hancher, M., Turubanova, S. A., Tyukavina, A., ... Townshend, J. R. G. (2013). High-Resolution Global Maps of 21st-Century Forest Cover Change. Science, 342(6160), 850-853.

Hoekstra, A. Y., \& Mekonnen, M. M. (2012). The water footprint of humanity. Proceedings of the National Academy of Sciences, 109(9), 3232- 3237.

Holifield, R., Porter, M., \& Walker, G. (2009). Introduction Spaces of Environmental Justice: Frameworks for Critical Engagement. Antipode, 41(4), 591-612.

Hornborg, A. (1998). Towards an ecological theory of unequal exchange: articulating world system theory and ecological economics. Ecological Economics, 25(1), $127-$ 136.

Howitt, R. (2003). Scale. In Agnew, F.,Mitchell, K., \& Toal, G. (Eds.), A Companion to Political Geography (pp. 132-157). Hoboken, NJ: Wiley-Blackwell.

Jorgenson, A. K. (2006). Unequal Ecological Exchange and Environmental Degradation: A Theoretical Proposition and Cross-National Study of Deforestation, 1990-2000*. Rural Sociology, 71(4), 685-712.

Kashwan, P. (2015). Integrating power in institutional analysis: A micro-foundation perspective. Journal of Theoretical Politics, 28(1), 5-26. 
Keck, M. E., \& Sikkink, K. (1998). Transnational Advocacy Networks in International Politics: Introduction. In M. E. Keck \& K. Sikkink (Eds.), Activists beyond borders. Advocacy Networks in International Politics (pp. 1-38). Ithaca, NY: Cornell University Press.

Leach, M., Raworth, K., \& Rockström, J. (2013). Between social and planetary boundaries: navigating pathways in the safe and just space for humanity (World Social Science Report 2013). Retrieved from OECD website: http://www.worldsocialscience.org/documents/wss-report-2013.pdf

Leguizamón, A. (2016). Disappearing nature? Agribusiness, biotechnology and distance in Argentine soybean production. The Journal of Peasant Studies, 43(2), 313-330.

Lele, S., Springate-Baginski, O., Lakerveld, R., Deb, D., \& Dash, P. (2013). Ecosystem Services: Origins, Contributions, Pitfalls, and Alternatives Conservation and Society, 11(4), 343-358.

Lenschow, A., Newig, J., \& Challies, E. (2016). Globalization's limits to the environmental state? Integrating telecoupling into global environmental governance. Environmental Politics, 25(1), 136-159.

Li, T. M. (2011). Centering labor in the land grab debate. The Journal of Peasant Studies, 38(2), 281-298.

Liu, J., Dou, Y., Batistella, M., Challies, E., Connor, T., Friis, C., ... Sun, J. (2018). Spillover systems in a telecoupled Anthropocene: typology, methods, and governance for global sustainability. Current Opinion in Environmental Sustainability, 33, 58-69.

Liu, J., Hull, V., Batistella, M., DeFries, R., Dietz, T., Fu, F., ... Zhu, C. (2013). Framing Sustainability in a Telecoupled World. Ecology and Society, 18(2).

Locke, J. (2005 [1690]). Second Treatise of Government (J. Bennett, Ed.). Retrieved from http://www.earlymoderntexts.com/assets/pdfs/locke1689a.pdf

Lundsgaard-Hansen, L., Schneider, F., Zaehringer, J., Oberlack, C., Myint, W., \& Messerli, P. (2018). Whose Agency Counts in Land Use Decision-Making in Myanmar? A Comparative Analysis of Three Cases in Tanintharyi Region. Sustainability, 10(10), 3823.

Martin, A. (2013). Global environmental in/justice, in practice: introduction. The Geographical Journal, 179(2), 98-104.

Martin, A., Coolsaet, B., Corbera, E., Dawson, N. M., Fraser, J. A., Lehman, I., \& Rodriguez, I. (2016). Justice and conservation: The need to incorporate recognition. Biological Conservation, 197, 254-261.

Martinez-Alier, J. (2009). Social Metabolism, Ecological Distribution Conflicts, and Languages of Valuation. Capitalism Nature Socialism, 20(1), 58-87.

Martinez-Alier, J., Temper, L., Del Bene, D., \& Scheidel, A. (2016). Is there a global environmental justice movement? The Journal of Peasant Studies, 43(3), 731-755.

McAteer, E., \& Pulver, S. (2009). The Corporate Boomerang: Shareholder Transnational Advocacy Networks Targeting Oil Companies in the Ecuadorian Amazon. Global Environmental Politics, 9(1), 1-30.

McGinnis, M. D. (2011). Networks of Adjacent Action Situations in Polycentric 
Governance. Policy Studies Journal, 39(1), 51-78.

Mejía Acosta, A. (2013). The Impact and Effectiveness of Accountability and Transparency Initiatives: The Governance of Natural Resources. Development Policy Review, 31(s1), s89-s105.

Nelson, P. (2002). New Agendas and New Patterns of International NGO Political Action. Voluntas: International Journal of Voluntary and Nonprofit Organizations, 13(4), 377-392.

Newig, J., Lenschow, A., Challies, E., Cotta, B., \& Schilling-Vacaflor, A. (2019). What is governance in global telecoupling? Ecology and Society, 24(3).

Nielsen, J. Ø., de Bremond, A., Chowdhury, R. R., Friis, C., Metternicht, G., Meyfroidt, P., ... Thomson, A. (2019). Toward a normative land systems science. Current Opinion in Environmental Sustainability, 38, 1-6.

Oberlack, C., Boillat, S., Brönnimann, S., Gerber, J.-D., Heinimann, A., Ifejika Speranza, C., ... Wiesmann, U. (2018). Polycentric governance in telecoupled resource systems. Ecology and Society, 23(1).

Oberlack, C., Tejada, L., Messerli, P., Rist, S., \& Giger, M. (2016). Sustainable livelihoods in the global land rush? Archetypes of livelihood vulnerability and sustainability potentials. Global Environmental Change, 41, 153-171.

Ostrom, E. (2005). Understanding Institutional Diversity. Princeton, NJ: Princeton University Press.

Pascual, U., Palomo, I., Adams, W. M., Chan, K. M. A., Daw, T. M., Garmendia, E., ... Phelps, J. (2017). Off-stage ecosystem service burdens: A blind spot for global sustainability. Environmental Research Letters, 12(7), 75001.

Pascual, U., Phelps, J., Garmendia, E., Brown, K., Corbera, E., Martin, A., ... Muradian, R. (2014). Social equity matters in payments for ecosystem services. Bioscience, 64, 1027.

Peluso, N. L., \& Lund, C. (2011). New frontiers of land control: Introduction. The Journal of Peasant Studies, 38(4), 667-681.

Rawls, J. (1971). A theory of justice. Cambridge, MA: Belknap.

Rice, J. (2007). Ecological Unequal Exchange: Consumption, Equity, and Unsustainable Structural Relationships within the Global Economy. International Journal of Comparative Sociology, 48(1), 43-72.

Rodriguez, I. (2013). Linking well-being with cultural revitalization for greater cognitive justice in conservation: lessons from Venezuela in Canaima National Park. Ecology and Society, 22(4).

Rodríguez, I., \& Inturias, M. L. (2018). Conflict transformation in indigenous peoples' territories: doing environmental justice with a 'decolonial turn.' Development Studies Research, 5(1), 90-105.

Schlosberg, D. (2007). Defining Environmental Justice. Theories, Movements, and Nature. Oxford, UK: Oxford University Press.

Schlosberg, D. (2013). Theorising environmental justice: the expanding sphere of a discourse. Environmental Politics, 22(1), 37-55.

Schröter, M., Koellner, T., Alkemade, R., Arnhold, S., Bagstad, K. J., Erb, K.-H., ... 
Bonn, A. (2018). Interregional flows of ecosystem services: Concepts, typology and four cases. Ecosystem Services, 31, 231-241.

Sen, A. (2009). The Idea of Justice. Cambridge, MA: Allen Lane \& Harvard University Press.

Sikor, T. (2014). The Justices and Injustices of Ecosystem Services. Oxford, UK: Routledge.

Sikor, T., Auld, G., Bebbington, A. J., Benjaminsen, T. A., Gentry, B. S., Hunsberger, C., ... Upton, C. (2013). Global land governance: From territory to flow? Current Opinion in Environmental Sustainability, 5(5), 522-527.

Sikor, T., Martin, A., Fisher, J., \& He, J. (2014). Toward an Empirical Analysis of Justice in Ecosystem Governance. Conservation Letters, 7(6), 524-532.

Spalding, R. J. (2017). Judicialization of Mining Conflict: Opportunities and Risks in Guatemala. Paper presented at the XXXV International Congress of the Latin American Studies Association. Lima, Peru.

Sun, J., Mooney, H., Wu, W., Tang, H., Tong, Y., Xu, Z., ... Liu, J. (2018). Importing food damages domestic environment: Evidence from global soybean trade. Proceedings of the National Academy of Sciences, 115(21), 5415-5419.

Temper, L. (2019). From boomerangs to minefields and catapults: dynamics of translocal resistance to land-grabs. The Journal of Peasant Studies, 46(1), 188-216.

Temper, L., Demaria, F., Scheidel, A., Del Bene, D., \& Martinez-Alier, J. (2018). The Global Environmental Justice Atlas (EJAtlas): ecological distribution conflicts as forces for sustainability. Sustainability Science, 13(3), 573-584.

Torres, S., Moran, E., \& Silva, R. (2017). Property Rights and the Soybean Revolution: Shaping How China and Brazil Are Telecoupled. Sustainability, 9(6), 954.

Towers, G. (2000). Applying the Political Geography of Scale: Grassroots Strategies and Environmental Justice. The Professional Geographer, 52(1), 23-36.

Vallejos, M., Volante, J. N., Mosciaro, M. J., Vale, L. M., Bustamante, M. L., \& Paruelo, J. M. (2015). Transformation dynamics of the natural cover in the Dry Chaco ecoregion: A plot level geo-database from 1976 to 2012. Journal of Arid Environments, 123, 3-11.

Veuthey, S., \& Gerber, J.-F. (2012). Accumulation by dispossession in coastal Ecuador: Shrimp farming, local resistance and the gender structure of mobilizations. Global Environmental Change, 22(3), 611-622.

Vijge, M. J., Metcalfe, R., Wallbott, L., \& Oberlack, C. (2019). Transforming institutional quality in resource curse contexts: The Extractive Industries Transparency Initiative in Myanmar. Resources Policy, 61, 200-209.

Villamayor-Tomas, S., \& García-López, G. (2018). Social movements as key actors in governing the commons: Evidence from community-based resource management cases across the world. Global Environmental Change, 53, 114-126.

Wallerstein, I. (1984). The Politics of the World-Economy. The States, the Movements and the Civilizations. Cambridge, UK: Cambridge University Press.

Xiong, H., Millington, J., \& Xu, W. (2018). Trade in the telecoupling framework: Evidence from the metals industry. Ecology and Society, 23(11). 
Young, I. M. (1990). Justice and the politics of difference. Princeton, NJ: Princeton University Press.

Yu, Y., Feng, K., \& Hubacek, K. (2013). Tele-connecting local consumption to global land use. Global Environmental Change, 23(5), 1178-1186.

Zaehringer, J. G., Schneider, F., Heinimann, A., \& Messerli, P. (2019). Co-producing Knowledge for Sustainable Development in Telecoupled Land Systems In C. Friis \& J. Ø. Nielsen (Eds.), Telecoupling: Exploring Land-Use Change in a Globalised World (pp. 357-381). London, UK: Palgrave Macmillan.

Zhai, Y., Lei, Y., Wu, J., Teng, Y., Wang, J., Zhao, X., \& Pan, X. (2017). Does the groundwater nitrate pollution in China pose a risk to human health? A critical review of published data. Environmental Science and Pollution Research, 24(4), 3640-3653.

Zhang, J., Zhao, N., Liu, X., \& Liu, Y. (2016). Global virtual-land flow and saving through international cereal trade. Journal of Geographical Sciences, 26(5), 619639.

Zhang, W., Wang, F., Hubacek, K., Liu, Y., Wang, J., Feng, K., ... Bi, J. (2018). Unequal Exchange of Air Pollution and Economic Benefits Embodied in China's Exports. Environmental Science \& Technology, 52(7), 3888-3898.

Zimmerer, K. S., Lambin, E. F., \& Vanek, S. J. (n.d.). Smallholder telecoupling and potential sustainability. Ecology and Society, 23(1). 
Supplementary material: Environmental justice aspects for integration into telecoupling research.

\begin{tabular}{|c|c|c|}
\hline Dimension & Key research questions & Possible approaches and methods \\
\hline \multirow[t]{3}{*}{$\begin{array}{l}\text { 1. Distributive } \\
\text { justice }\end{array}$} & $\begin{array}{l}\text { 1.1. What is the } \\
\text { distribution of the benefits } \\
\text { and burdens of social- } \\
\text { ecological interactions } \\
\text { across distant regions? }\end{array}$ & $\begin{array}{l}\text { Ecological benefits: interregional flows of ecosystem } \\
\text { services (Schröter et al., 2018) Ecological burdens: off- } \\
\text { stage ecosystem service burdens (distant, delayed and } \\
\text { diffuse negative effects on ecosystems) (Pascual et al., } \\
\text { 2017) } \\
\text { Direct social effects of telecouplings: distribution of } \\
\text { labour, terms of trade and entitlements }\end{array}$ \\
\hline & $\begin{array}{l}\text { 1.2. How are these benefits } \\
\text { and burdens felt and } \\
\text { perceived by affected } \\
\text { people? }\end{array}$ & $\begin{array}{l}\text { "Bottom-up" accounts on felt benefits and burdens in } \\
\text { terms of perceptions (Daw, Brown, Rosendo, \& Pomeroy, } \\
\text { 2011; Dawson \& Martin, 2015) }\end{array}$ \\
\hline & $\begin{array}{l}\text { 1.3. How are these benefits } \\
\text { and burdens distributed } \\
\text { among differentiated social } \\
\text { groups? }\end{array}$ & $\begin{array}{l}\text { Social differentiation of burdened/benefited people: } \\
\text { capabilities and well-being (Dawson \& Martin, 2015) }\end{array}$ \\
\hline \multirow[t]{4}{*}{$\begin{array}{l}\text { 2. Procedural } \\
\text { justice }\end{array}$} & $\begin{array}{l}\text { 2.1. What are the relevant } \\
\text { decision-making spaces in } \\
\text { telecoupling processes? }\end{array}$ & $\begin{array}{l}\text { Spaces and scales that induce, coordinate and respond to } \\
\text { telecouplings (Newig, Lenschow, Challies, Cotta, \& } \\
\text { Schilling-Vacaflor, 2019) } \\
\text { Spaces that govern focal and distant territories and flows } \\
\text { between them (Oberlack et al., 2018) }\end{array}$ \\
\hline & $\begin{array}{l}\text { 2.2. Who are affected by } \\
\text { these decision-making } \\
\text { spaces? }\end{array}$ & $\begin{array}{l}\text { All-subjected principle (Fraser, 2010) } \\
\text { Social connection model (Young, 2006) }\end{array}$ \\
\hline & $\begin{array}{l}\text { 2.3. To what extent can } \\
\text { those affected take } \\
\text { autonomous decisions? }\end{array}$ & $\begin{array}{l}\text { Compare actors with decision-making power with those } \\
\text { affected (Lundsgaard-Hansen et al., 2018) }\end{array}$ \\
\hline & $\begin{array}{l}\text { 2.4. What is the decision- } \\
\text { making power of those } \\
\text { affected and left aside? }\end{array}$ & $\begin{array}{l}\text { Observable, hidden and invisible power forms (Gaventa, } \\
2006) \\
\text { Networks of action situations (Oberlack et al., 2018) } \\
\text { Policy resources analysis (Knoepfel, Larrue, Varone, \& } \\
\text { Hill, 2011) }\end{array}$ \\
\hline $\begin{array}{l}\text { 3. Recognition } \\
\text { justice }\end{array}$ & $\begin{array}{l}\text { 3.1. What are the implicit } \\
\text { framings and value systems } \\
\text { embedded in the }\end{array}$ & $\begin{array}{l}\text { Qualitative assessment of information flows: discourses, } \\
\text { scale choices, evidence framing, views on nature and }\end{array}$ \\
\hline
\end{tabular}




\section{References}

Álvarez, L., \& Coolsaet, B. (2018). Decolonizing Environmental Justice Studies: A Latin American Perspective. Capitalism Nature Socialism, 1-20.

Daw, T., Brown, K., Rosendo, S., \& Pomeroy, R. (2011). Applying the ecosystem services concept to poverty alleviation: the need to disaggregate human well-being. Environ. Conserv., 38, 370.

Dawson, N., \& Martin, A. (2015). Assessing the contribution of ecosystem services to human wellbeing: A disaggregated study in western Rwanda. Ecological Economics, 117, 62-72.

Fraser, N. (2010). Injustice at Intersecting Scales: On 'Social Exclusion' and the 'Global Poor.' European Journal of Social Theory, 13(3), 363-371.

Gaventa, J. (2006). Finding the Spaces for Change: A Power Analysis. IDS Bulletin, 37(6), 23-33.

Knoepfel, P., Larrue, C., Varone, F., \& Hill, M. (2011). Public Policy Analysis. Bristol, UK: The Policy Press.

Lundsgaard-Hansen, L., Schneider, F., Zaehringer, J., Oberlack, C., Myint, W., \& Messerli, P. (2018). Whose Agency Counts in Land Use Decision-Making in Myanmar? A Comparative Analysis of Three Cases in Tanintharyi Region. Sustainability, 10(10), 3823.

Martin, A., Akol, A., \& Gross-Camp, N. (2015). Towards an Explicit Justice Framing of the Social Impacts of Conservation. Conservation and Society, 13(2), 166-178.

Newig, J., Lenschow, A., Challies, E., Cotta, B., \& Schilling-Vacaflor, A. (2019). What is governance in global telecoupling? Ecology and Society, 24(3).

Oberlack, C., Boillat, S., Brönnimann, S., Gerber, J.-D., Heinimann, A., Ifejika Speranza, C., ... Wiesmann, U. (2018). Polycentric governance in telecoupled resource systems. Ecology and Society, 23(1).

Pascual, U., Palomo, I., Adams, W. M., Chan, K. M. A., Daw, T. M., Garmendia, E., ... Phelps, J. (2017). Off-stage ecosystem service burdens: A blind spot for global sustainability. Environmental Research Letters, 12(7), 75001.

Rodríguez, I., \& Inturias, M. L. (2018). Conflict transformation in indigenous peoples' territories: doing environmental justice with a 'decolonial turn.' Development Studies Research, 5(1), 90-105.

Schröter, M., Koellner, T., Alkemade, R., Arnhold, S., Bagstad, K. J., Erb, K.-H., ... Bonn, A. (2018). Interregional flows of ecosystem services: Concepts, typology and four cases. Ecosystem Services, 31, 231-241.

Young, I. M. (2006). Responsibility and global justice: a social connection model. Social Philosophy and Policy, 23(1), 102-130. 